BBALIP 5.3744

\title{
Secretion-coupled increase in the catalytic activity of rat hepatic lipase
}

\author{
Adrie J.M. Verhoeven and Hans Jansen \\ Department of Bioktemistn 1. Erasmus Unit crsity Rotterdam (The Netherlands)
}

(Received 24 May 1991)

Key words: Hepatic lipase; Enzyme activity: Immunoinhibition: Synthesis; Maturation: Glycosylation: (Rat hepatecyte)

Freshly isolated rat hepatocytes synthesize and secrete hepatic lipase (HL). Comparison of secreted HL with intracellular HL indicates a secretion-linked increase in the specific enzyme activity. (a) Immunotitration with polyclonal anti-HL showed a 3-5-fold lower specific enzyme activity of intracellular HL than of secreted HL. This was confirmed by ELISA using a mixture of monoclonal anti-HL's. (b) After isolation on Sepharose-heparin, a similar difference in specific enzyme activity was observed, whereas the apparent $K_{m}$ for glyceroltrioleate was not different. (c) $\mathrm{H}_{i}$, activity secreted in the absence of protein de novo synthesis was 5 -fold higher than was accounted for by the fall in intracellular activity, whereas HL protein lost from the cells was near-completely recovered in the extracellular medium. (d) The presence of inactive HL protein was demonstrated in cells treated with castanospermine, which inhibits secretion of newly synthesized HL by interfering with maturation at an early stage of $\boldsymbol{N}$-linked oligosaccharide processing. Upon removal of castanospermine, secretion of $\mathrm{HL}$ activity recovered, even when protein de novo synthesis was inhibited, strongly suggesting that part of the inactive $H L$ was mobilized and became activated. This secretion-coupled increase in HL activity in the absence of protein synthesis suggests the existence of inactive precursor within rat hepatocytes. The catalytic activity of HL becomes apparent apon maturation of the protein after oligosaccharide processing by the rough endoplasmic reticulum glucosidases.

\section{Introduction}

Hepatic lipase (HL) is a lipolytic enzyma that plays a central role in lipoprotein metabolism. It is present in the liver of most vertebrates where it is localized at the extracellular surface of endothelial cells lining the blood sinusoids and from where it can be released by heparin infusion [1]. HL is synthesized and constitutively secreted by liver parenchymal cells. Post-heparin HL. activity is lower in patients with angiographic evidence for coronary atherosclerosis than in patients without such signs [2]. In addition, HL activity correlated with the development of coronary atherosclerosis in patients

\footnotetext{
Abbreviations: BSA, bovine serum albumin: CHAPS, 3-[(3-cholamidopropyl)dimethylammonio]-l-propane-sulfonate; HL, hepatic lipase; IgG, immunoglobulin G; LPL, lipoprotein lipase; PAGE, polyacrylamide gelelectrophoresis; PBS, Dulbecco's phosphate-buffered saline; PMSF, phenylmethylsulfonyl fluoride; SDS, sodium dodecyl sulfate.
}

Correspondence: A.J.M. Verhoeven, Dept. Biochemistry I. Erasmus University, POB 1738,3000 DR Rotterdam. The Netherlands. on a lipid-lowering diet [3]. HL is thought to reduce atherosclerotic risk, either by reducing the number of atherogenic particles in circulation, such as IDL [4] and chylomicron-remnants $[5,6]$, or by contributing to reverse cholesterol tratisport by facilitating the delivery of $\mathrm{HDL}$ cholesterol to the liver $[1,7,8]$. A number of in vivo and in vitro studies has indicated that expression of $\mathrm{HL}$ activity is under hormonal and dietary control [1,9-14]. This control might be exerted at the level of HL binding to the endothelium [11], or by synthesis, intracellular degradation and secretion in the hepatocytes $[9,12]$.

Rat HL in heparin-containing liver perfusates, and secreted by isolated parenchymal cells, is a glycoprotein with $M_{\mathrm{r}} 58000$ on SDS-PAGE [15-17]. In liver homogenates, and in rat hepatoma cells or freshly isolated hepatocytes, a form of HL has been detected with a lower $M_{\mathrm{r}}$ of approx. 53000 [16-18]. Pulse-label studies have established a precursor-product relationship, the $53 \mathrm{kDa}$-form being the high-mannose type intermediate of the mature, complex type protein [1618]. Once secreted, the mature protein shows full cat- 
alytic activity. How enzyme activity of iritracellular HL relates to the process of maturation is unknown.

In an attempt to address this issus, we determined the specific enzyme activity of int:acellular HL and found it to be much lower than that of secreted HL. This might indicate the existenc; of inactive, or less active, HL within the cells. For lirioprotein lipase (LPL), which is closely related to $\mathrm{HL}$, ilso inactive forms have been detected within adipocy ies $[19,20]$. The inactive LPL molecules were hypothesized to represent the precursor form of active enzyme $[19,20]$, or LPL protein after partial intracellular degradacion [20]. Recently, however, Ailhaud and co-workers $[21,22]$ showed that intracellular LPL could be activated in vitro by merc dilution of cell lysates into buffer. This led the authors to suggest that intracellular LPL molecules are stored in a condensed state, which masks their catalytic activity. These observations prompted us to study the possible existence of inactive, intracellular forms of $\mathrm{HL}$ into greater detail. The immunological data presented here strongly suggest the existence within freshly isolated rat hepatocytes of inactive HL molecules, which unlike LPL, cannot be activated in vitro.

\section{Materials and Methods}

\section{Materials}

Castanospermine and $N$-methyldeoxynojirimycin were purchased from Genzyme (Boston MA, U.S.A.), whereas cycloheximide and CHAPS were from Boehringer Mannheim (F.R.G.). Glycerol tri[9,10(n)$\left.{ }^{3} \mathrm{H}\right]$ oleate and $\left[9,10(n) \cdot{ }^{3} \mathrm{H}\right]$ oleic acid were obtained from Amersham International (U.K.), at specific radioactivities of 1 and $2.5 \mathrm{Ci} / \mathrm{mmol}$, respectively. Heparin (Thromboliquine) was a product of Organon Teknika (Boxtei, The Netherlands). Sepharose-heparin was prepared from CNBr-activated Sepharose 4B (Pharmacia, Uppsala, Sweden) according to the manufacturers instructions. Ham F10 medium was obtained from Flow Lab (U.K.) and bovine serum was from BioTrading (Wilnis, The Netherlands). Alkaline phosphatase-conjugated goat anti-mouse IgG was purchased from Tago (Burlingame CA, U.S.A.) and p-nitrophenol phosphate and oleic acid were from Merck (Darmstadt, F.R.G.). All other chemicals were from Sigma. Polystyrene 96well EIA plates (code 3590) were from Costar (Cambridge MA, U.S.A.).

\section{Antibodies}

An antiscrum was raised in a goat against rat $\mathrm{HL}$ purified to homogencity from liver perfusates by the method of Jensen and Bensadoun [15]. The lgG-fraction was purified from plasma by two successive precipitations each with $50 \%\left(\mathrm{NH}_{4}\right)_{2} \mathrm{SO}_{4}$ and $17 \% \mathrm{Na}_{2} \mathrm{SO}_{4}$ followed by extensive dialysis against Dulbecco's phosphate-buffered saline (PBS). Final protein concentra- tion was $20 \mathrm{mg} / \mathrm{ml}$. The titer of this preparation was determined by immunoinhibition of HL activity from a liver perfusate (see below), and amounted to approx. $3500 \mathrm{mU} / \mathrm{ml}$. Non-specific IgG's, isolated similarly from the serum of a non-immunized goat, failed to inhibit HL activity. In a Western blot of a heparin-containing liver perfusate, a single protein with $M_{\mathrm{r}} 58000$ corresponding to $\mathrm{HL}$ was recognized by the anti-HL IgG preparation, but not by the control IgG's (data not shown).

The monoclonal antibody preparation used here was a mixture of five different hybridoma supernatants which have been described in detail previously [23]. The titer of this preparation amounted to approx. 20 $\mathrm{mU} / \mathrm{ml}$.

\section{Hepatocyte isolation and incubation}

Hepatocytes were isolated from male Wistar rats (250-300 g body weight) by collagenase perfusion, and non-parenchymal ceils were removed by differential centrifugation as described previously [24]. Cell viability was tetermined by Trypan blue exclusion and ranged from 85 to $90 \%$. The cells were suspended at a density of approx. $4.10^{6}$ cells $/ \mathrm{ml}$ in Ham F10 medium containing $50 \mathrm{U} / \mathrm{ml}$ of heparin and $20 \%$ of heat-inactivated rat or bovine serum [25]. Cell suspensions were incubated at $37^{\circ} \mathrm{C}$ under an atmosphere of $5 \% \mathrm{CO}_{2} / 95 \%$ $\mathrm{O}_{2}$ in a shaking water bath. At the times indicated, samples of cell suspension were collected. The cells were separated from the medium by centrifugation ( $50 \times g, 2 \mathrm{~min}$, room temp.), and the cell-free medium was used for analysis of secreted HL. For analysis of intracellular lipase, the cells were washed once in PBS and finally resuspended at $30 \cdot 10^{6}$ cells $/ \mathrm{ml}$ in PBS containing heparin $(50 \mathrm{U} / \mathrm{ml})$, PMSF ( $1 \mathrm{mM}$; from a $200 \mathrm{mM}$ stock solution in methanol), benzamidine (1 $\mathrm{mM})$, leupeptin $(10 \mu \mathrm{g} / \mathrm{ml})$, aprotinin $(1.5 \mu \mathrm{g} / \mathrm{ml})$ and EDTA (1 mM). This suspension was rapidly frozen to $-80^{\circ} \mathrm{C}$. After slow thawing on ice, the cells were sonified for three cycles of 5-10 s (MSE 150, amplitude $10 \mu$, on ice). Thereafter, the homogenates were centrifuged $\left(10 \mathrm{~min}, 10000 \times \mathrm{g}, 4^{\circ} \mathrm{C}\right)$, and the supernatant was assayed for HL.

\section{Hepatic lipase acticity}

HL activity is defined here as the lipase activity that was sensitive to immunoinhibition with polyclonal antiHL antibodies. Lipase activities were determined by a triacylglycerol hydrolase assay at pH 8.5 in $0.6 \mathrm{M} \mathrm{NaCl}$ using a gum acacia stabilized glycerol $\left[{ }^{3} \mathrm{H}\right]$ trioleate emulsion as substrate [25]. Assays were performed for $30 \mathrm{~min}$ at $30^{\circ} \mathrm{C}$ and a substrate concentration of 3.2 $\mathrm{mM}$, unless otherwise stated. At the end of the assay, the free fatty acids were extracted [25]. In a standard assay, never more than $120 \mathrm{nmol}$ of fatty acids (10\% of total substrate) were released. Enzyme activities were 
expressed as $\mathrm{mU}$ ( $\mathrm{nmol}$ of free fatty acids released per $\min$.

In immunoinhibition tests, $40 \mu \mathrm{l}$ of cell-free media and $40 \mu 1$ of properly diluted cell homogenates were mixed with $10 \mu \mathrm{l}$ of the polyclonal anti-HL preparation described above. After incubation for $1 \mathrm{~h}$ at $0^{\circ} \mathrm{C} .75 \mu \mathrm{l}$ of substrate was added and residual lipase activity was determined. In the experiments reported here, more than $70 \%$ and $95 \%$ of total lipase activity in cell homogenates and cell-free media, respectively, was inhibited by preincubation with anti-HL.

Control experiments showed quantitatively similar results when cell homogenates were assayed in the absence or presence of $20 \%$ serum (data not shown); dilutions of cell homogenates were therefore routinely made in PBS without serum. The triacylglycerol content of cell homogenates amounted to $1.2 \pm 0.1 \mathrm{mM}$ (mean \pm S.D., $n=3$ ), which would result in a dilution of radiolabelled substrate of only $10 \%$ with the highest amount of homogenate used per assay. The efficiency of free fatty acid extraction, which was quantified by using a gum acacia stabilized emulsion of unlabelled trioleate containing [ ${ }^{3} \mathrm{H}$ ]oleic acid (specific radioactivity $1.6 \mathrm{mCi} / \mathrm{mmol}$; final concentration in the assay 125 $\mu \mathrm{M}$ ), amounted to $60.3 \pm 1.6 \%$ (mean \pm S.D., $n=20$ ). This value was not significantly different between assays on cell-free media and cell homogenates (data not shown). Enzyme activity data were not corrected for this extraction efficiency.

In experiments designed to determine the $\mathrm{pH}$ dependency of lipase activity, the buffers $(0.1 \mathrm{M})$ used in the substrate mixture were sodium acetate $(\mathrm{pH} 4.0$ and $\mathrm{pH} 5.0$ ), sodium phosphate (pH 5.8, $\mathrm{pH} 6.6$ and $\mathrm{pH}$

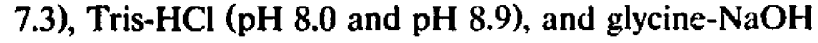
(pH 9.6 and pH 10.3).

\section{ELISA for rat hepatic lipase}

A solid-phase ELISA was developed for rat HL using the goat polyclonal and the mixture of monoclonals described above as the primary and secondary antibody, respectively [26]. In short, microtiter plate wells were coated with $20 \mu \mathrm{g}$ of the goat anti-HL IgG. After blocking with $1 \%$ gelatin in PBS, the wells were incubated successively with: (i) sample; (ii) the monoclonal antibodies at a 1:5 dilution, and (iii) alkaline phosphatase-conjugated goat anti-mouse $\lg G$ af a $1: 500$ dilution. To reduce non-specific binding, incubations were performed in the presence of $1 \mathrm{M} \mathrm{NaCl}, 0.1 \%$ Tween-20 and $0.5 \%$ BSA in PBS. Finally, alkaline phosphatase was assayed using $p$-nitrophenol phosphate, and absorbances were read at $405 \mathrm{~nm}$ in a Titertek EIA analyzer. For each plate used in the ELISA, serial dilutions of purified HL were included as standards. Rat HL was purified from post-heparin liver perfusates exactly as described by Jensen and Bensadoun [15] but with omission of the last gel-filtra- tion step. The final preparation contained $338 \mu \mathrm{g} / \mathrm{ml}$ of protein, and was stored at $-80^{\circ} \mathrm{C}$ until use. The standard curves showed the ELISA to be sensitive from 10 to $1000 \mathrm{ng} / \mathrm{ml}$.

\section{Affinty chromatography}

To enable partial purification of intracellular and extracellular HL by affinity chromatography on Sepharose-heparin, the heparin concentration used in the secretion experiments and in the preparation of cell homogenates was reduced to $10 \mathrm{U} / \mathrm{ml}$. Samples $(2.5 \mathrm{ml})$ of secretion media and corresponding cell homogenates were applied to $1 \mathrm{ml}$ of Sepharoseheparin poured in a Pasteur pipette. The column was washed with $2.5 \mathrm{ml}$ of $0.2 \mathrm{M} \mathrm{NaCl}$ in a $10 \mathrm{mM}$ sodium phosphate buffer ( $\mathrm{pH} 7.2$ ) containing $20 \%$ glycerol (by vol.). Bound enzyme was eluted from the column with $1 \mathrm{ml}$ portions of the same buffer containing successively, 0.4, 0.6, 0.8, 1.0, 1.2 and $2.0 \mathrm{M} \mathrm{NaCl}$. The entire procedure was performed at $4{ }^{\circ} \mathrm{C}$. Total recovery of lipase activity was $82 \pm 18 \%$ and $90 \pm 13 \%$ (mean \pm S.D., , =4) for the secretion media and cell homogenates, respectively.

\section{Other methods}

For the determination of kinetic parameters, the glycerol tri[ [ $\left.{ }^{3} \mathrm{H}\right]$ oleate emulsion was serially diluted with $5 \%(\mathrm{w} / \mathrm{v})$ gum acacia in $8 \mathrm{mM} \mathrm{NaHCO}(\mathrm{pH} 9)$, to yield final concentrations of 9.6 to $0.3 \mathrm{mM}$ in the assay mixture. Assays were performed as described above. The kinetic parameter $V_{\operatorname{mix}}$ (maximal velocity) was estimated from the linear part of Hanes plots, and the parameters $K_{\mathrm{m}}^{\mathrm{app}}$ (apparent substrate half-saturation constant) and $h$ (Hill coefficient) were subseguently estimated from Hill plots using the method of least squares [27].

Protein was determined by the method of Bradford [28] using BSA as standard. The triacylglycerol content of cell homogenates was determined after Folch extraction [29] using a Boehringer test kit. Statistical significances were determined by Student's $t$-test.

\section{Results}

\section{Assay of intracellular $H L$ actitity}

Fig. 1A shows the relationship between the anount of cell homogenate used in the assay and the lipase activity measured. The release of free fatty acids from the ${ }^{3} \mathrm{H}$-labelled trioleate substrate increased linearly with homogenate volumes up to approx. $5 \mu$ l per assay, where about $1 \mathrm{nmol}$ of fatty acius was released. At higher volumes, product formation levelled off, and above $20 \mu \mathrm{l}$ per assay no further release of fatty acids was cbserved (Fig. 1A). With the cell-free media, however, free fatty acids increased linearly with sample volumes at least up to $15 \mathrm{nmol}$ of product (Fig. lA), 

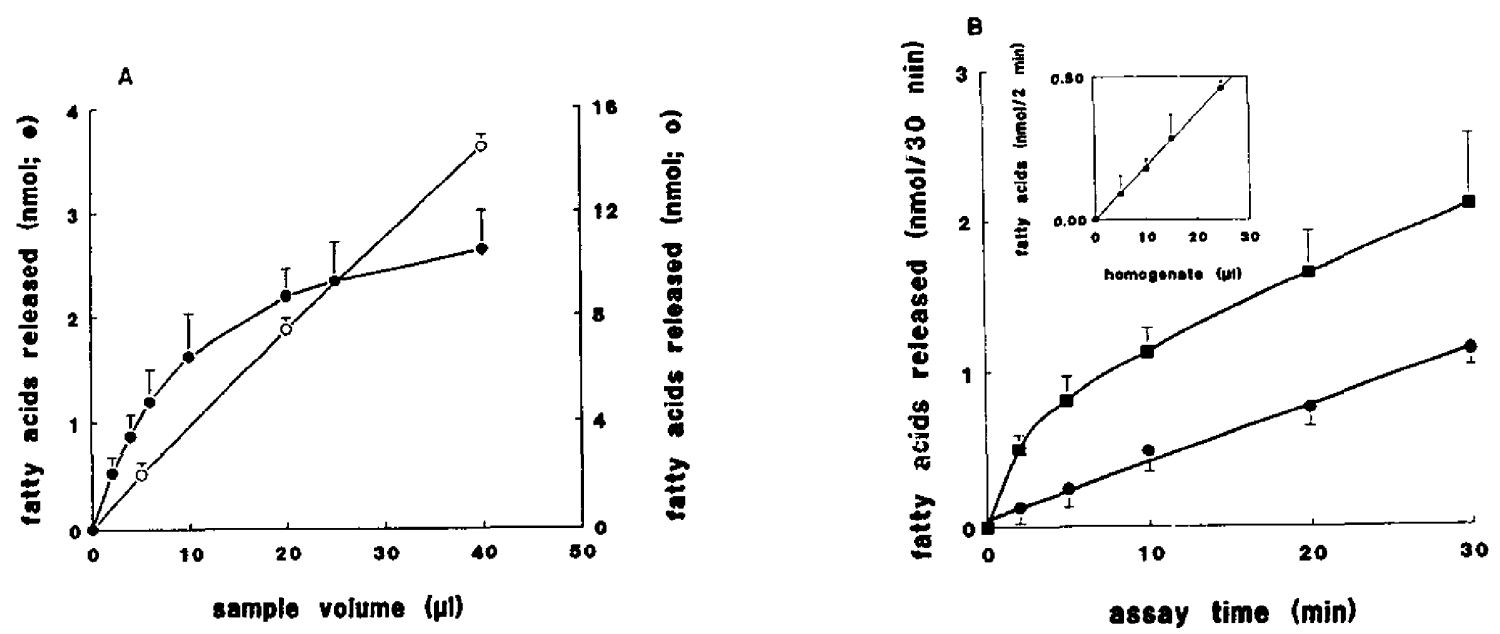

Fig. 1. Optimalization of the lipase assay on cell homogenates. Freshly isolated rat hepatocytes were washed with several volumes of cold PBS containing $50 \mathrm{U} / \mathrm{m}$ l of heparin to remove any extracellularly bound HL [40]. Homogenates were prepared by freeze-thawing and sonification, as described in the Methods section. A cell-free medium containing secreted HL was prepared after a 2 h-incubation of freshly isolated rat hepatocytes with $20 \%$ serum and $50 \mathrm{U} / \mathrm{ml}$ of heparin. In A, different amounts of the homogenate $(\bullet)$ and cell-free medium (O) were tested for HL activity in the standard 30-min assay. In B, the relation of HL activity with assay time was measured using either $5 \mu l(\bullet)$ or $25 \mu l(\square)$ of cell homogenate; for the cell-free medium fatty acid release was linear with assay time throughout incubation, even when tested at $50 \mu l$ per assay (data not shown). Insert: the effect of various amounts of homogenate was determined on the initial rate of triacylglycerol hydrolysis, measured as the number of fatty acids released after $2 \mathrm{~min}$ of incubation. Data are expressed as means \pm S.D. $(n=4)$.

ruling out the possibility of limiting substrate at the higher homogenate volumes. When the data on fatty acid release were expressed as $\mathrm{mU} / \mathrm{ml}$ of homogenate, a 5-fold increase in lipase activity became apparent upon an 8-fold dilution into heparin-containing buffer. No additional effect was observed upon further dilution.

A number of observations indicate that the mechanism of in vitro activation differs from that described for LPL [20,21]. The dilution effect on HL activity appears independent of detergents as similar dose-response curves were obtained when diluted in $4 \mathrm{mM}$ CHAPS or $0.02 \%$ Triton X-100 (data not shown). As shown in Fig. 1B, fatty acids were released at a constant rate during the 30 -min assay with $5 \mu \mathrm{l}$ cell homogenate. At $25 \mu \mathrm{l}$, however, product formation showed biphasic kinetics with a rapid burst during the initial few minutes, and a slow second phase thereafter. The rate of product formation during this second phase was slightly higher than that observed with $5 \mu$ l homogenate. The initial burst in fatty acid production increased linearly with sample volumes (Fig. 1B, insert). Hence, the dilution effect was not apparent when intracellular HL activity was measured as the initial rate of product formation. Recombination of various amounts of cell homogenate with a constant amount of a liver perfusate containing HL activity indicated the presence of an inhibitory compound in the cell homogenate (Fig. 2). Above $10 \mu \mathrm{l}$ of cell homogenate, HL activity in the perfusate and the homogenate were no longer additive, and at $25 \mu \mathrm{l}$ of homogenate, only $60 \%$ of total activity was detected. Inhibition was not due to PMSF [30] or any of the other proteinase inhibitors used, as a similar inhibition was observed when prepared in their absence. Moreover, ultrafiltration through a membrane with $\mathbf{3 0 0 0 0}$ molecular weight cutoff failed to remove the inhibitory activity (data not shown). The inhibitor was lost after heating the homogenate for $10 \mathrm{~min}$ at $56^{\circ} \mathrm{C}$, or after extraction with acetone:diethyl ether $(1: 1, \mathrm{v} / \mathrm{v})$. No further attempts were made to identify this inhibitory compound.

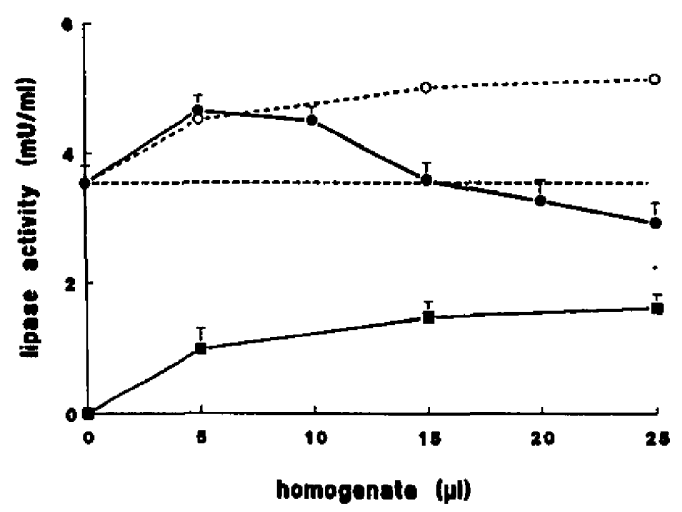

Fig. 2. Effect of homogenate on the HL activity in a liver perfusate. Various amounts of a cell homogenate were tested for HL activity, either alone ( $\square$ ), or immediately after mixing with a constant amount of $\mathrm{HL}$ activity from a liver perfusate $(3.5 \pm 0.3 \mathrm{mU} / \mathrm{ml} ; \bullet)$. HL activity measured in the combined samples was compared with the sum of the activities measured separately $(O)$. At homogenate vol. umes of $15 \mu l$ and above, the values measured were significantly lower than those calculated $(P<0.05 ; n=4)$. The activity in the liver perfusate was not affected by the addition of the homogenization buffer (after freeze-thawing) alone (- - $)$. 
These observations indicate that the dilution effect on HL activity is due to the presence of an inhibitor in the cell homogenate. Apparently, this inhibitory compound is diluted to below a critical concentration when tested at $5 \mu \mathrm{l}$ homogenate and less. In all subsequent assays of intracellular HL activity, $5 \mu$ l of homogenate were tested. Using this assay, $13 \pm 3 \mathrm{mU} / \mathrm{ml}$ (mean \pm S.D., $n=8$ ) of HL activity were detected in liver cell homogenates, which correspunds to approx, $0.4 \mathrm{mU}$ per $10^{\mathrm{h}}$ cells.

Comparison between intracellular and extracellular $H L$

Immunotitration of intracellular $\mathrm{HL}$ and $\mathrm{HL}$ secreted in vitro by freshly isolated hepatocytes showed inhibition of intracellular HL activity with polyclonal anti-HL at much higher amounts of antibody (Fig. 3). In three independent experiments, 4 to 5-times more anti-HL antibody was required to inhibit a similar amount of enzyme activity present in a cell homogenate than that of extracellular HL. When the amount of HL protein was measured by an ELISA for rat $H L$, the specific enzyme activity of secreted, extracellular $\mathrm{HL}$ amounted to $9 \pm 5 \mathrm{mU} / \mu \mathrm{g}$, whereas that of intracellular $\mathrm{HL}$ was $1.8 \pm 0.9 \mathrm{mU} / \mu \mathrm{g}$ (means \pm S.D., $n=6 ; P<0.01$ ). Hence, the specific enzyme activity of intracellular HL was 5 -fold less than that of secreted HL.

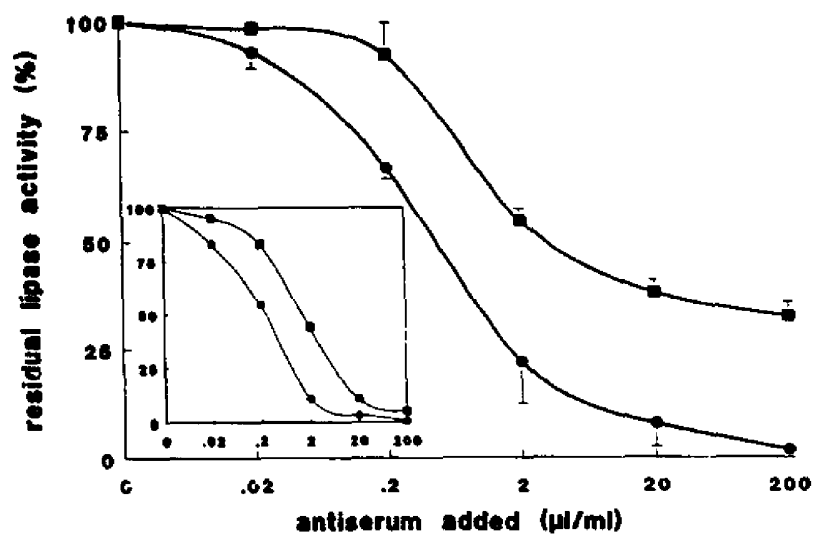

Fig. 3. Immunotitration of intracellular and secreted HL. A cell homogenate and cell-free medium were prepared from a control suspension after a $2 \mathrm{~h}$-incubation with $50 \mathrm{U} / \mathrm{ml}$ of heparin. After pre-incubation for $1 \mathrm{~h}$ at $0^{\circ} \mathrm{C}$ with different amounts of polyclonal anti-HL, substrate was added to a final concentration of $9.6 \mathrm{mM}$, and residual lipase activity was assayed. The cell-free medium (•) was diluted with Ham F10 containing $20 \%$ serum and $50 \mathrm{U} / \mathrm{ml}$ heparin to obtain an activity comparable to the cell homogenate $(\omega)$. Results are expressed as the percentage of $\mathrm{HL}$ activity measured after incubation with non-immune IgG, which amounted to 1.3 and 1.6 $\mathrm{mU} / \mathrm{ml}$ for the cell-free medium and cell homogenate, respectively. Data are representutive of three similar experiments. Insert: Immunotitration of intracellular ( $\square$ ) and secreted ( $\bullet$ ) HL activity after partial purification on Sepharose-heparin. Respective HL activities were 2.0 and $2.3 \mathrm{mU} / \mathrm{ml}$. Data are representative of four similar experiments.

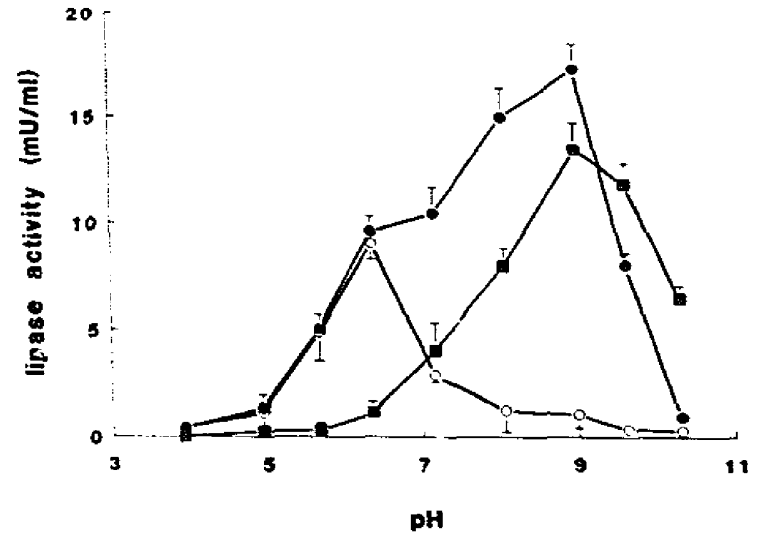

Fig. 1. pH dependency of intracellular lipase and secreted HL. Hepatocytes were incubated for 2 ì in control medium containing $20{ }^{\circ} ;$ serum and $50 \mathrm{U} / \mathrm{ml}$ heparin and cell homogenates $(0 . \bullet)$ and cell-free media (a) were prepared. After pre-incubation for $1 \mathrm{~h}$ at $0^{\circ} \mathrm{C}$ with either non-immune IgG $(\bullet$,$) ) or polyclonal anti-HL (\mathrm{c})$ triacylglycerol hydrolase activity was determined at different assay pHs. Data are expressed as means \pm S.D. $(n=4)$.

\section{Characterization of intracellular $H L$ acticity}

The lipase activity of HL secreted in vitro showed a sharp optimum at pH 8.9-9.5 (Fig. 4), similar to that for HL in a liver perfusate (data not shown). In contrast, the lipase activity of control cells showed a broad $\mathrm{pH}$ optimum at $\mathrm{pH}$ 6.5-9. After pre-incubation with polyclonal anti-HL, lipase activities measured at $\mathrm{pH} 8$ and above were abolished, whereas activities below $\mathrm{pH}$ 7 remained unaffected. In homogenates prepared from cycloheximide-treated cells (see below), lipase activity showed a $\mathrm{pH}$ dependency similar to the latter curve, i.e., that obtained with the control homogenates after immunoinhibition with anti-HL (data not shown). These findings confirm previous reports on the presence of multiple lipase activities within rat liver [31], and demonstrate a similar $\mathrm{pH}$ dependency for extracellular and intracellular HL activity. Moreover, these data indicate that, of all intracellular lipases, cycloheximide-treatment selectively affects HL activity under the conditions used here.

The HL activity in cell-free media and cell homogenates both showed slightly sigmoidal kinetics with respect to the glycerol-trioleate substrate (not shown). Estimated Hill coefficients were in the range of 1.2 to 1.7. and were not significantly different from each other (Table I). $K_{\mathrm{m}}^{\text {:app }}$ values were significantly higher for HL in homogenates than in cell-free media. Addition of a $5 \mu$ l-sample of homogenate to $45 \mu 1$ of extracellular HL induced a similar upward shift in $K_{m}^{\text {iap }}$ of the latter without affecling $V_{\max }$ or h fnot shown). This observation suggests that the homogenate contains a compound that reduces the affinity of $\mathrm{HL}$ for its substrate. 
Partial purification of $H L$ on Sepharose-heparin

Of the HL activity present in a cell homogenate, only $25 \pm 10 \%$ (means \pm S.D., $n=4$ ) was bound to Sepharose-heparin, whereas virtually all HL activity in secretion media was bound. In both cases, bound activity eluted at $0.6 \mathrm{M} \mathrm{NaCl}$. After isolation, the dilution effect on intracellular HL was no longer observed. immunotitration with polyclonal anti-HL showed inhibition of intracellular HL activity at 3-4-fold higher amounts of antibody than for secreted HL (Fig. 3, insert), indicating that the difference in specific enzyme activity was maintained throughout isolation. After isolation, the $K_{\mathrm{m}}^{\mathrm{app}}$ of intracellular HL was markedly reduced to a value that was no longer different from that of secreted HL (Table I). The estimated Hill coefficient was not affected by the isolation procedure. These data indicate that, except for the 3-4-fold difference in specific enzyme activity, intracellular and secreted HL have similar kinetic properties.

\section{Effect of cycloheximide and castanospermine}

Incubation of hepatocytes with cycloheximide completely blocks protein de novo synthesis but leaves the secretion of intracellular HL from a pre-existing pool intact [26]. After $2 \mathrm{~h}$ of incubation, intracellular $\mathrm{HL}$ activity was completely depleted (Fig. 5). Simultaneously, the amount of Hi. protein was markedly reduced. Castanospermine, which interferes with HL maturation by inhibiting $N$-linked oligosaccharide processing at the level of trimming glucosidases in the rough endoplasmic reticulum, also leaves secretion of HL already processed beyond this point unaffectcd [26]. After $2 \mathrm{~h}$ of incubation with this inhibitor, HL activity was no longer detectable intracellularly. The amount of HL protein was also reduced with respect to the untreated controls, but substantial amounts of HL protein remained detectable. In five independent experiments, the amount of HL protein in castanospermine-treated cells was significantly higher than that in

\section{TABLE I}

Kinetic parameters of intracellular and secreted $H \mathrm{~L}$

The kinetic parameters $K_{n+1}^{\mathrm{ipp}}$ and $\mathrm{h}$ (Hill coefficient) were determined as described in the Methods section for HL triacylglycerol hydrolase activity, either directly in cell homogenates and cell-free media, or after isolation on Sepharose-heparin. Data are means $\underline{1}$. S.D. for three to five independent experiments

\begin{tabular}{lll}
\hline Enzyme preparation & $K_{\mathrm{m}}^{\mathrm{apr}}(\mathrm{mM})$ & $\mathrm{h}$ \\
\hline Secreted HL & & \\
$\quad$ cell-free medium & $1.4 \pm 0.2$ & $1.5 \pm 0.2$ \\
after isolation & $0.8 \pm 0.1$ & $1.4 \pm 0.1$ \\
$\quad$ & \\
Intracellular HL & & $1.3 \pm 0.2$ \\
$\quad$ cell homogenate & $4.6 \pm 1.0$ & $1.2 \pm 0.1$ \\
$\quad$ after isolation & $0.9 \pm 0.3$ & \\
\hline
\end{tabular}

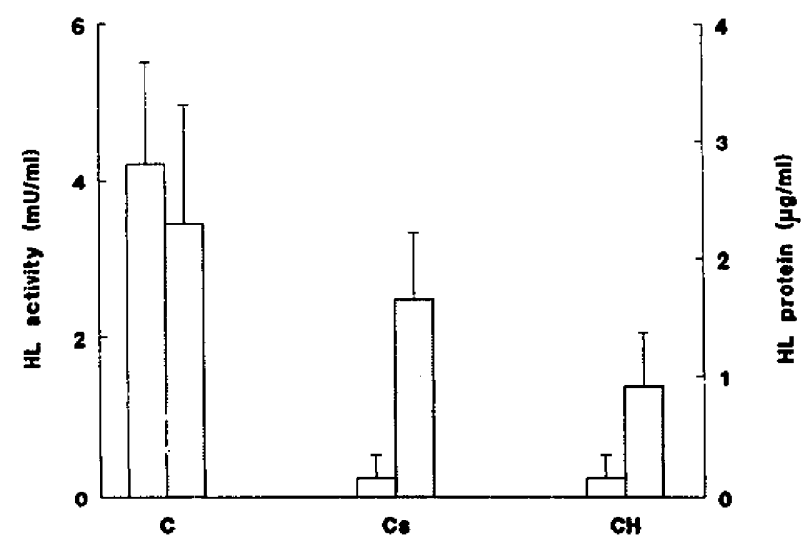

Fig. 5. Effect of castanospermine and cycloheximide on intracellular HL. Hepatocytes were incubated for $2 \mathrm{~h}$ in the absence of any inhibitor $(\mathrm{C})$, or in the presence of $100 \mu \mathrm{g} / \mathrm{ml}$ castanospermine $(\mathrm{Cs})$ or $10 \mu \mathrm{g} / \mathrm{ml}$ of cycloheximide (CH). At the end of the incubation. cell homogenates were prepared and analyzed for $\mathrm{HL}$ activity (open bars) and HL protein by ELiGA (closed bars). Data are means \pm S.D. of five independent experiments.

cycioheximide-treated cells $(P<0.05$, by paired Student's $t$-test). Similar results were obtained with $N$ methyldeoxynojirimycin, an alternate inhibitor of trimming glucosidases (data not shown). These observations suggest the presence of inactive HL within the cells.

\section{Secretion-coupled increase in specific $H L$ activity}

Cells were first washed with several volumes of cold PBS containing $50 \mathrm{U} / \mathrm{ml}$ of heparin to remove any extracellularly bound $\mathrm{HL}$, and then incubated for $2 \mathrm{~h}$ with cycloheximide. No further HL secretion occurred upon prolonged incubation [26]. HL protein and activity we measured in the cell homogenates prepared just before addition of cycloheximide, and in the cellfree media prepared at the end of the 2 h-incubation. The ELISA revealed that the amount of $\mathrm{HL}$ protein that disappeared from the cells during the incubation was completely recovered in the extracellular medium. In five indepencient experiments, the secretion potential, taken as the ratio of total secreted amount to the lost cellular amount, was $1.3 \pm 0.3$ (mean \pm S.D., $n=5$ ). In contrast, more HL activity was secreted than was initially present within the cells; for HL activity, the secretion potential amounted to $5.2 \pm 2.1$ (mean \pm S.D., $n=5$ ). Apparently, the specific enzyme activity of HL increased approx, 4-fold upon secretion.

\section{Recolery from castanospermine inhibition}

We then tested whether the inactive HL detected in castanospermine-treated cells was still available for further maturation and secretion. After $2 \mathrm{~h}$ of incubation with castanospermine, the inhibitor was removed by washing the cells in PBS followed by incubation of the cells without castanospermine. HL activity became 


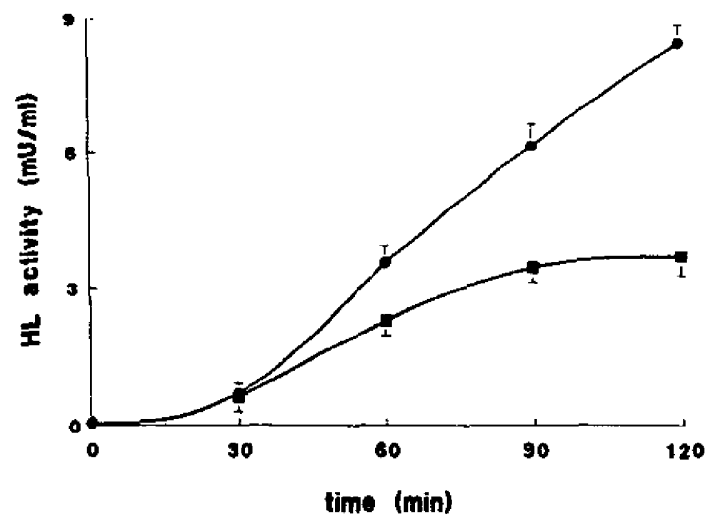

Fig. 6. Recovery from castanospermine inhibition. Hepatocytes were pre-incubated for $2 \mathrm{~h}$ in the presence of 100$) \mu \mathrm{g} / \mathrm{ml}$ castitnospermine. After washing the cells free of inhibitor. incubation was continued either in the absence $(\bullet)$ or presence of $10 \mu \mathrm{g} / \mathrm{ml}$ cycloheximide (ם). At the times indicated. samples were withdrawn for analysis of secreted HIL activity. Data are means \pm S.D. of four independent experiments.

detectable in the extracellular medium after a lag-time of approx. $30 \mathrm{~min}$ (Fig. 6). Thereafter, secretion proceeded at a constant rate throughout incubation. When cycloheximide was present during recovery from castanospermine inhibition, considerable amounts of $\mathrm{HL}$ activity were secreted into the extracellular medium. Again, secretion was delayed by approx. $30 \mathrm{~min}$. Now, secretion proceeded at a lower rate than in the absence of cycloheximide, and completely stopped after $90 \mathrm{~min}$. After $2 \mathrm{~h}$ of incubation, the specific enzyme activity of $\mathrm{HL}$ in the extracellular medium was $7.7 \pm 2.3$ and $8.9 \pm 2.9 \mathrm{mU} / \mu \mathrm{g}$ in the presence and absence of cycloheximide, respectively (means \pm S.D., $n=4 ; P>0.1$ ). These data suggest that at least part of the inactive $H L$ protei.: observed in castanospermine-treated cells was mobilized for further maturation and secretion, during which the catalytic activity of HL protein became detectable.

\section{Discussion}

This study demonstrates, by immunotitration with polyclonal anti-HL (Fig. 3), and by triacylglycerol hydrolase assays combined with ELISA using a mixture of monoclonal anti-HL's, that the specific enzyme activity of intracellular $\mathrm{HL}$ is 3- to 5-fold lower than that of extracellular HL. Upon secretion into the extracellulas medium, the specific catalytic activity of HL increased approx. 5-fold. This indicates that of all intracellular HL protein, only $\mathbf{2 0 - 2 5 \%}$ is fully active. Alternatively, all intracellular HL protein might be equaily active but at a specific activity of only $20-25 \%$ of that of secreted HL. The latter possibility seems unlikely, as HL protein with virtually no catalytic activity could be demonstrated in cycloheximide- and castanospermine- treated hepatocytes (Fig. 5). Inactive forms of $\mathrm{HL}$ might either be the product of intracellular degradation, or represent an inactive precursor of the functionally mature protein. In the presence of heparin and cycloheximide the cells were depleted of HL activity, but part of immunoreactive protein remained within the cells (Fig. 5). This residual protein may represent intracellularly inactivated HL. The finding that castanospermine-treated cells, containing only inactive $\mathrm{HL}$ (Fig. 5), were able to secret. fully active enzyme even in the absence of protein de novo synthesis (Fig. 6), strongly argues in favor of a precursor-product relationship. Hence, the occurrence of intracellular activation of HL in rat hepatocytes is clearly indicated.

For LPL. which belongs to the same gene family as HL (Ref. 32, and references therein), inactive intracellular forms have been demonstrated in 3T3-L1 adipocytes [20], whereas a secretion-linked increase in the specific catalytic activity was shown to occur in some mouse adipocytes and in rat stromal-vassular cells [19,21.22,33]. In $\mathrm{Ob} 17$ adipocytes. intracellular activation of LPL occurred after LPL protein exits from the endoplasmic reticulum and before it reaches the trans-Golgi cisternae [19]. Activation of LPL molecules in 3T3-F422A cells appears closely associated with the formation of LPL dimers [34], which occurs within the Golgi apparatus. In this oligomerization process, $N$-linked oligosaccharide processing appears to play a permissive role as improperly glycosylated LPL fails to form dimers and accumulates within the endoplasmic reticulum in an inactive form [19,34-36]. Transport of LPL protein to the Golgi enables oligosaccharide processing to the mature form which then associates to catalytically active dimers [34].

At which stage during maturation the catalytic activity of HL becomes detectable remains unknown, but it is attractive to suppose a model similar to that for the activation of LPL. First, native $\mathrm{HL}$ is also thought to be an oligomeric protein $[15,37]$. Secondly, interference with $N$-linked oligosaccharide prccessing using castanospermine or methyldeoxynojirimycin induces a marked decrease in the specific catalytic activity of intracellular HL (Fig. 5). Both agents are inhibitors of the trimming glucosidases present in the rough endoplasmic reticulum [38], thus preventing the removal of the terminal glucose residues from core-glycosylated HL. Removal of these sugar residues appears essential to the efficient transport to the Golgi for some secretory glycoproteins [39], including HL [26]. Thirdly, the interpretation that of all intracellular HL protein approx. $75 \%$ is inactive, fits with a model that the activation process occurs rather late during maturation. In this respect it is noteworthy that $\mathrm{HL}$ is not stored in secretory vesicles but rapidly secreted from hepatocytes $[16,17]$. For Fu5AH rat hepatoma cells treated with heparin, the total transit time of HL was esti- 
mated at $31 \mathrm{~min}$, whereas the half-residence time in the endoplasmic reticulum-cis Golgi region was estimated at $25 \mathrm{~min}[17,40]$, indicating extremely rapid secretion of HL from the Golgi. For rat hepatocytes, the observed $30 \mathrm{~min} \mathrm{lag}$ in the recovery of HL secretion from castanospermine inhibition (Fig. 6), as well as the lag observed between inhibition of protein de novo synthesis and inhibition of HL secretion [26] are in accordance with such short intracellular transit times.

The mechanism of intracellular HL activation remains unknown. Although $N$-linked oligosaccharide processing appears important, as illustrated by the effect of castanospermine and methyldeoxynojirimycin, the activity state of the protein is probably only indirectly determined by its glycan structure (see above). In a recent report [35], Doolittle and co-workers claim that unglycosylated $\mathrm{HL}$ obtained after site-directed mutagenesis was secreted by transfected cells and was catalytically active, but further details werc not given. Probably, other post-translational modifications of the HL protein are involved. Alternatively, HL protein may be potentially active, but its activity is masked throughout most of intracellular transportation. In recent studies using adipocytes and muscle cells, Ailhaud and co-workers $[21,22]$ showed that active LPL molecules are stored intracellularly in a condensed state which masks catalytic activity. Unmasking was achieved in vitro by mere diiution of the cell lysate. We observed a similar dilution effect for $\mathrm{HL}$ in homogenates prepared from rat liver cells (Fig. 1). However, even when assayed at the proper dilutions, or after isolation on Sepharose-heparin, the specific catalytic activity of intracellular HL remained less than that of secreted HL. Moreover, recombination experiments with a liver perfusate indicated the presence in homogenates of inhibitory compounds (Fig. 2) that reduce the affinity of HL for its triacylglycerol substrate. Apparently, dilution of the cell homogenates was required to reduce the inhibitory compound in the assay. The nature of this inlibitor remains presently unknown.

\section{References}

1 Jansen, H. and Hïlsmann, W.C. (1985) Biochem. Soc. Trans, 13 , $24-26$.

2 Barth, J.D., Jansen, H., Hugenholtz. P.G. and Birkenhäger, J.C. (1983) Atherosclerosis 48, 235-241.

3 Barth, J.D., Jansen. H., Kromhout, D., Reiber, J.H.C.. Birkenhäger, J.C. and Arntzenius, A.C. (1987) J. Cardiovasc. Pharmacol. 10 (Suppl. 9). S42-S46.

4 Goldberg, I.J., Lee, N.-A., Paterniti, J.R., Ginsberg, H.N., Lindgren. F.T. and Brown, W.V. (1982) J. Clin. Invest. 70, 1184-1192.

5 Sultan, F. Lagrange, D., Jansen, H. and Griglio, S. (199()) Biochim. biophys. Acta 1042, 150)-152.

6 Weintraub, M.S., Eisenberg. S. and Breslow, J.l. (1987) J. Clin. Invest. $79.1110-1119$.
7 Bamberger, M., Lund-Katz, S., Phillips, M.C. and Rothblat, G.H. (1985) Biochemistry 24, 3693-3701.

8 Jansen. H. and Hülsmann. W.C. (1980) Trends Biochem. Sci. 5 , $265-268$.

9 Nakai. T., Yamada, S. Tamai. T., Kobayashi. T.. Hayashi, T. and Takeda. R. (1979) Metabolism 28, 30-40.

10 Tikkanen, J.J. and Nikkilä. E.A. (1987) Am. Hearł J. 113. 562-567.

II Schoonderwoerd, K., Hülsmann, wi.C. and Jansen, H. (1983) Biochim. Biophys. Acta 754, 279-283.

12 Schoonderwoerd, K.. Hülsmann. W.C. and Jansen. H. (1989) Lipids 24, 1039-1042.

13 Hansson. P.. Jensen, E.. Floren, C.N. and Nilsson-Ehle, P. (1986) Horm. Metab. Res. 18, 107- 109.

14 Busch. S.. Barnart. R.L., Martin, G.A.. Flanagan, M.A. and Jackson. R.L. (1990) J. Biol. Chem. 265, 22474-22479.

15 Jensen, G.L, and Bensidoun, A. (1981) Anal. Biochem. 113. 246-252.

16 Laposata, E.A., Laboda, M.M., Glick, J.M. and Strauss, J.F., III. (1987) J. Biol. Chem. 262, 5333-5338.

17 Cisar, L.A. and Bensadoun, A. (1987) Biochim. Biophys. Acta 927, 305-314.

18 Doolittle, M.H., Wong. H., Davis, R.C. and Schotz, M.C. (1987) J. Lipid Res. 28, 1326-1334.

19 Vannier, C., Amri, E.+Z., Etienne, J., Négrel, R. and Ailhaud, G. (1985) J. Biol. Chem. 260, 4424-4431,

20 Olivecrona, T,, Chernick, S.S., Bengtsson-Olivecrona, G., Garrison, M. and Scow, R.O. (1987) J. Biol. Chem. 262, 10748-10759.

21 Vannier. C., Deslex, S., Pradines-Figuères, A. and Ailhaud, G. (1989) J. Biol. Chem. 264, 13199-13205.

22 Pradines-Figuères, A., Vannier, C. and Ailhaud, G. (1990) J. Lipid Res. 31, 1467-1476.

23 Persoon, N.L.M., Sips, H.J., Hülsmann, W.C. and Jansen, N. (1986) Biochim. Biophys. Acta 875, 286-292.

24 Seglen, P.O. (1976) Methods Cell. Biol. 13, 29-8?.

25 Jansen, H., Kalkman, C., Zonneveld, A.J. and Hülsmann, W.C. (1979) FEBS Lett. 98, 299-302.

26 Verhoeven, A.J.M, and Jansen, H. (1990) J. Lipid Res. 31, $1883-1393$.

27 Cornish-Bowden, A. (1979) in Fundamentals of Enzyme Kinetics, pp. 25-28; pp. 152-159, Butterworth and Co, Ltd., London.

28 Bradford, M.M. (1976) Anal. Biochem. 72, 248-254.

29 Folch, J., Lees, M. and Sloane-Stanley, G.H. (1957) J. Biol. Chem. 226, 497-508.

30 Brady, L., Brzozowski, A.M., Derewenda, Z.S., Dodson, E., Dodson, G., Tolley, S., Turkenburg, J.P., Christiansen, L., Huge-Jensen, B., Norskov, L., Thim, L. and Menge, U. (1990) Nature 343, 767-770.

31 De Beer. L.J., Thomas, J., Mannaerts, G. and De Schepper, P.J. (1977) J. Clin. Invest. 59. !85-192.

32 Cai, S.-J., Wong, D.M., Chen, S.-H. and Chan, L. (1989) Biochemistry 28, 8966-8971.

33 Pradines-Figuères, A., Vannier, C. and Ailhaud, G. (1988) Biochim. Biophys. Res. Comm. 154, 982-990.

34 Vannier, C. and Ailhaud, G. (1989) J. Biol. Chem. 264, 1320613216.

35 Doolittle, M.H., Ben-Zeev, O., Elovson, J., Martin, D. and Kirchgessner. T.G. (1990) J. Biol. Chem. 265. 4570-4577.

36 Masuno, H., Blanchette-Mackie, E.J., Chernick, S.S. and Scow, R.O. (1990) J. Biol. Chem. 265, 1628-1638.

37 Twu. J.-S.. Garfinkel, A.S. and Schotz, M.C (1984) Biochim. Biophys. Acta 792. 330-337.

38 Fuhrmann, U., Bause, E. and Ploegh, H. (1985) Biochim. Biophys. Acta 825, 95-110.

39 Lodish, H.F. and Kong, N. (1984) J. Cell Biol. 98. 1720-1729.

40 Cisar, L.A.. Melford. K.H., Sensel, M. and Bensadoun, A. (1989) Biochim. Biophys. Acta 1004. 196-204. 